\title{
Differential Effects of Nitrogen Supply on Skin Pigmentation and Flesh Starch Breakdown of 'Gala' Apple
}

\author{
Huicong Wang \\ Department of Horticulture, Cornell University, 134A Plant Science, Ithaca, \\ NY 14853; and the Department of Horticulture, South China Agricultural \\ University, Guangzhou 510642, P.R. China
}

\author{
Lailiang Cheng ${ }^{1}$ \\ Department of Horticulture, Cornell University, 134 A Plant Science, Ithaca, \\ NY 14853
}

Additional index words. anthocyanins, chlorophylls, color, firmness, Malus domestica, maturity, soluble solids concentration, yield

\begin{abstract}
Apple maturity is often assessed by starch hydrolysis index, skin color, soluble solids, flesh firmness, and the rate of ethylene evolution. In red-fruited apple cultivars, the intensity and extent of coloration is an important consideration in determining the time of fruit harvest. Negative relationships have been found between tree nitrogen (N) status and fruit skin pigmentation, but how $\mathrm{N}$ affects flesh starch breakdown has not been examined in detail. The objective of this study was to determine how $\mathrm{N}$ supply affects flesh starch breakdown relative to skin color development. Seven-year-old 'Gala'/M.26 trees were provided with four levels of $\mathrm{N}(8.8,26.4,52.7$, and $105.4 \mathrm{~g} \mathrm{~N}$ per tree) in a modified Hoagland's solution. The effects of $\mathrm{N}$ supply on yield, fruit quality, and fruit maturation were evaluated. At harvest, fruit in the lowest $\mathbf{N}$ treatment was significantly smaller and had lower soluble solids but higher starch concentration, better color, and higher firmness than those grown at higher $\mathbf{N}$ supplies. Increasing $\mathbf{N}$ supply decreased both anthocyanin synthesis and chlorophyll degradation in fruit skin. Flesh starch concentration was higher at higher $\mathbf{N}$ supply at 38 days before harvest but was lower at higher $N$ supply at harvest. Starch degradation was completed earlier during cold storage with increasing $\mathrm{N}$ supply. These results indicate that increasing $\mathrm{N}$ supply delays skin red color development but accelerates flesh starch degradation in 'Gala' apples. These differential effects of $N$ supply should be taken into account when assessing fruit maturity for optimizing harvest time.
\end{abstract}

Nitrogen management is critical for achieving high yield and good fruit quality in commercial apple production (Sanchez et al., 1995) because tree growth, fruit yield, and quality are dependent on $\mathrm{N}$ supply. Within a certain range of $\mathrm{N}$ supply, increasing $\mathrm{N}$ supply leads to larger fruit and higher soluble solids in 'Gala' apple (Xia et al., 2009). However, red-fruited cultivars grown under high $\mathrm{N}$ supply often have poor color.

The intensity and extent of coloration is an important consideration in determining harvest time for red-fruited apple cultivars. Early work by Magness et al. (1940) showed a negative relationship between leaf $\mathrm{N}$ content and

Received for publication 8 Apr. 2011. Accepted for publication 16 June 2011.

This work was supported in part by Hatch Funds from Cornell Agricultural Experiment Station and New York Apple Research and Development Program. The 'Gala' trees used in this study were generously donated by Van Well Nursery, and the nutrients were provided by GreenCare Fertilizers. We gratefully acknowledge the technical assistance of Richard Raba and Jackie Nock.

${ }^{1}$ To whom reprint requests should be addressed; e-mail LC89@Cornell.edu. fruit skin color in 'Rome Beauty' apple. Since then, it has been reported in many studies that fruit coloration decreases as the rate of $\mathrm{N}$ application increases (Fallahi et al., 2001, 2006; Saito, 1995; Week et al., 1952). This decrease in coloration with increasing $\mathrm{N}$ application is presumably caused by the inhibition of $\mathrm{N}$ on anthocyanin synthesis and accumulation. However, delayed chlorophyll degradation might have also contributed. Higher rates of $\mathrm{N}$ were associated with greener fruit in 'Golden Delicious' (Meheriuk et al., 1992; Neilsen et al., 1984).

Although the effect of $\mathrm{N}$ supply on coloration of apples has been well documented, much less attention has been paid to its effect on other aspects of fruit maturity. Because maturity at harvest greatly affects apple fruit quality and storage performance, starch hydrolysis indices (starch content), soluble solids concentration (SSC), flesh firmness, and the rate of ethylene evolution are often measured in addition to skin color to indicate the maturity stage of apple for making decisions on harvest time. $\mathrm{N}$ supply does not necessarily affect all the fruit maturity indices in the same manner. High $\mathrm{N}$ application was found to enhance preharvest fruit drop of 'McIntosh' apples (Hoffman, 1940). High N application was later reported to enhance ethylene evolution and respiration of 'Fuji' apple at harvest (Fallahi et al., 2001) and ethylene evolution of 'Starkspur Golden Delicious' apple after cold storage (Fallahi et al., 1985). Neilsen et al. (2006) observed that 'Gala' apple trees receiving low N supply at 0 to 4 weeks after bloom had lower starch index (higher starch) in fruit at harvest than those receiving high $\mathrm{N}$ supply during the same period or low $\mathrm{N}$ supply at later times. Fallahi et al. (2001) also noticed that 'Fuji' apple trees receiving low $\mathrm{N}$ supply had a slightly lower starch index (slightly higher starch) than those at higher $\mathrm{N}$ supply. All these observations suggest that fruit maturity might be advanced by high $\mathrm{N}$ supply. The objective of this study was to determine the effects of $\mathrm{N}$ supply on flesh starch degradation relative to the skin pigmentation in 'Gala' apple.

\section{Materials and Methods}

Plant material and nitrogen treatments. Seven-year-old 'Gale Gala'/M.26 trees were grown in 55-L black plastic pots in acidwashed sand $(\mathrm{pH} 6.2)$ at a spacing of $1.07 \times$ $3.35 \mathrm{~m}$ (equivalent to 2790 trees/ha) in eastwest rows at Cornell Orchards in Ithaca, NY (lat. $42^{\circ} 26^{\prime} \mathrm{N}$, long. $76^{\circ} 29^{\prime} \mathrm{W}$; elevation 500 $\mathrm{m})$. They were trained in tall spindle $(\approx 3.6 \mathrm{~m}$ tall) and had produced regular crops in the previous 4 years. Uniform trees were selected before budbreak in 2007, and each tree was fertigated with 4 L of Hoagland's No. 2 solution (Hoagland and Arnon, 1950) at one of four $\mathrm{N}$ concentrations twice per week from bloom (11 May) to 2 weeks before harvest, except during active shoot growth when the trees were fertigated three times per week. The $\mathrm{N}$ concentration used during active shoot growth was 5.0, 15.0, 30.0, or $60 \mathrm{~mm}$ (from $\mathrm{NH}_{4} \mathrm{NO}_{3}$ ), but when shoot growth slowed down, the $\mathrm{N}$ concentrations were lowered. The weekly supply of $\mathrm{N}$ for the trees in the four $\mathrm{N}$ treatments is shown in Figure 1. Each tree received a total of $8.8,26.4,52.7$, and $105.4 \mathrm{~g}$ actual $\mathrm{N}$ from bloom to harvest, which is equivalent to $24.5,73.5,147.0$, or $294.0 \mathrm{~kg} \cdot \mathrm{ha}^{-1}$ of actual N. Each N treatment was replicated five times with a single tree

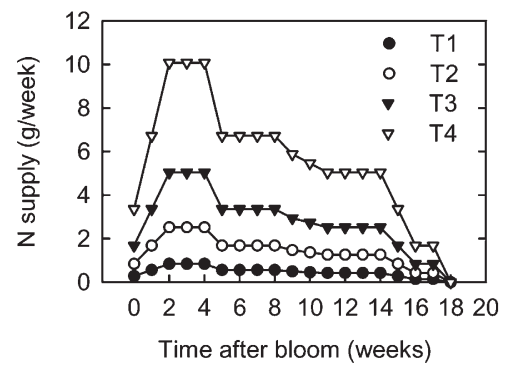

Fig. 1. Supply patterns of four levels of nitrogen (T1, T2, T3, and T4) for 7-year-old 'Gala') M.26 apple trees during the growing season of 2007. The total amount of nitrogen $(\mathrm{N})$ provided in $\mathrm{T} 1, \mathrm{~T} 2, \mathrm{~T} 3$, and T4 during the growing season is $8.8,26.4,52.7$, and $105.4 \mathrm{~g}$ per tree, respectively. 
per replicate in a completely randomized design. Irrigation was provided with two spray sticks per tree and the trees were well watered throughout the growing season. The cropload of these trees was adjusted to 8.0 fruit $/ \mathrm{cm}^{2}$ trunk cross-sectional area by hand thinning when the king fruit was $10 \mathrm{~mm}$, and this cropload was maintained to fruit harvest. All the trees received standard disease and insect control throughout the growing season.

Twenty leaves per tree were taken from the middle of the extension growths at $90 \mathrm{~d}$ after bloom for leaf $\mathrm{N}$ analysis.

Assessment of fruit quality. Fruit color was measured on five fruit per tree both at 3 weeks before harvest and at harvest. Three color measurements (non-overlapping, $50 \mathrm{~mm}^{2}$ in size) were made at the exposed side and the shaded side of each fruit with a chroma meter (CR-310; Minolta, Japan) using the Hunter "L," "a," "b," and hue values. The lightness coefficient, "L," represents brightness and darkness, "a" value represents greenish to redness as the values increase from negative to positive, and " $b$ " value represents bluish to yellowish. Hue value was calculated from "a" and "b" values: $h=$ [ATAN(b/a)/6.2823*360 (a > 0, b > 0)];
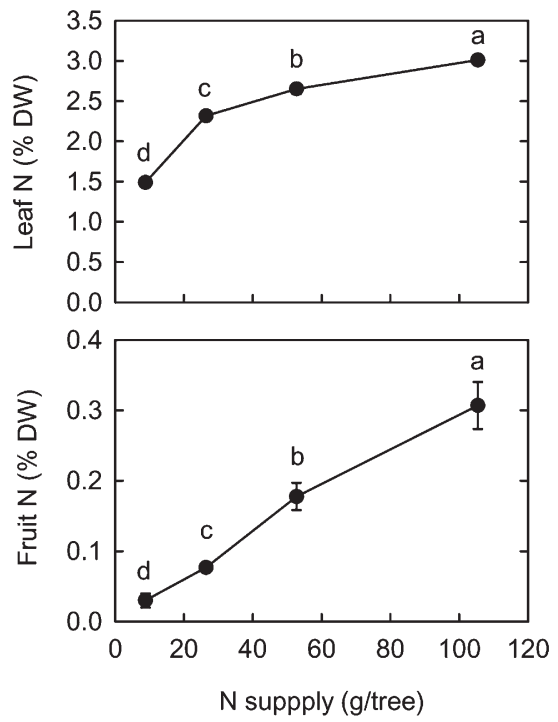

Fig. 2. Leaf and fruit nitrogen (N) status of 'Gala'/ M.26 trees in response to $\mathrm{N}$ supply levels. Leaf samples were taken at $90 \mathrm{~d}$ after bloom and fruit samples were taken at harvest. Different letters indicate significant difference using the least significant difference test at the 0.05 level.
$[\operatorname{ATAN}(\mathrm{b} / \mathrm{a}) / 6.2823 * 360+180(\mathrm{a}<0, \mathrm{~b}>$ $0)$ ]; [ATAN(b/a)/6.2823*360 + $360(\mathrm{a}>0$, $\mathrm{b}<0)$ ] (Voss, 1992). The lower the hue value, the redder the fruit skin color.

Fruit number, fruit yield per tree, and average fruit weight were measured at fruit harvest on 18 Sept. 2007. Forty well-exposed fruit from each tree were picked randomly at harvest, divided into five groups with eight fruit each, weighed, and placed in perforated polyethylene bags. One group was evaluated for various quality attributes at harvest. The other four groups of fruit were stored at $2{ }^{\circ} \mathrm{C}$ and evaluated for quality at 5 -week intervals for a total of 20 weeks. Fruit firmness was measured from the two peeled sides of each fruit by an EPT-1-R Penetrometer (Lake City Technical Products Inc., Kelowna, British Columbia, Canada). Soluble solids concentration $(\%)$ was measured from the expressed juice of the fruit used for firmness test with an Atago ATA-60 PAL-1 portable digital refractometer (Atago USA, Inc., Bellevue, WA). The remaining fruit tissues were peeled and cut equatorially, frozen in liquid $\mathrm{N}_{2}$, and stored at $-80^{\circ} \mathrm{C}$ for fruit $\mathrm{N}$ and starch measurements.

Measurements of anthocyanins and chlorophylls. Peel discs $\left(1 \mathrm{~cm}^{2}\right.$ in size) on the sun-exposed side of fully exposed fruit were selected for uniformity in color and taken at $83 \mathrm{~d}$ after full bloom (DAFB) (when pigmentation just began), 111 DAFB, and at harvest (130 DAFB), respectively, frozen in liquid $\mathrm{N}_{2}$, and stored at $-80{ }^{\circ} \mathrm{C}$ until analysis. Total anthocyanins were determined following the method of Fuleki and Francis (1968), which involves the measurement of the absorbance at $520 \mathrm{~nm}$ on samples diluted with $\mathrm{pH} 1.0$ and 4.5 buffers. Two peel discs were extracted with $3 \mathrm{~mL}$ of methanol:water: $\mathrm{HCl}$ $(85: 12: 3, \mathrm{v} / \mathrm{v})$ and kept in the dark at room temperature overnight. Peel chlorophyll content was measured according to Arnon (1949).

Fruit starch analysis. The frozen apple flesh tissues were pulverized and then extracted with $80 \%$ (v/v) ethanol three times (3 $\mathrm{mL}$ each for $30 \mathrm{~min})$. The pellets were boiled in $2 \mathrm{~mL}$ of $0.2 \mathrm{M} \mathrm{KOH}$ for $30 \mathrm{~min}$, adjusted the $\mathrm{pH}$ to 4.5 with $1 \mathrm{~mL} 1 \mathrm{M}$ acetic acid, and then digested with 50 units of amyloglucosidase (EC 3.2.1.3) at $55^{\circ} \mathrm{C}$ for $30 \mathrm{~min}$. Starch was determined as glucose equivalents according to Chen et al. (2002).

Measurements of leaf and fruit nitrogen. Leaf samples were dried in a forced-air oven and ground as described before (Cheng and Raba, 2009). Frozen fruit tissues were pulverized and freeze-dried. Tissue $\mathrm{N}$ was measured

Table 1. Yield, fruit size, firmness, and soluble solids concentration (SSC) of 'Gala' apple fruit at harvest as affected by different levels of nitrogen $(\mathrm{N})$ fertigation.

\begin{tabular}{cccccc}
\hline $\begin{array}{l}\mathrm{N} \text { treatments } \\
(\mathrm{g} \mathrm{N} / \text { tree })\end{array}$ & $\begin{array}{c}\text { Yield } \\
(\mathrm{kg} / \text { tree })\end{array}$ & $\begin{array}{c}\text { Yield efficiency } \\
\left(\mathrm{kg} \cdot \mathrm{cm}^{-2} \mathrm{TCA}\right)\end{array}$ & $\begin{array}{c}\text { Fruit wt } \\
(\mathrm{g} / \text { fruit })\end{array}$ & $\begin{array}{c}\text { SSC } \\
\left({ }^{\circ} \text { Brix }\right)\end{array}$ & $\begin{array}{c}\text { Firmness } \\
(\mathrm{N})\end{array}$ \\
\hline 8.8 & $17.8 \mathrm{~b}$ & $1.33 \mathrm{~b}$ & $155.1 \mathrm{c}$ & $13.6 \mathrm{~b}$ & $80.1 \mathrm{a}$ \\
26.4 & $18.6 \mathrm{~b}$ & $1.58 \mathrm{a}$ & $181.2 \mathrm{~b}$ & $14.6 \mathrm{a}$ & $74.1 \mathrm{~b}$ \\
52.7 & $20.9 \mathrm{a}$ & $1.64 \mathrm{a}$ & $197.6 \mathrm{a}$ & $15.2 \mathrm{a}$ & $71.7 \mathrm{bc}$ \\
105.4 & $19.9 \mathrm{ab}$ & $1.53 \mathrm{a}$ & $191.3 \mathrm{ab}$ & $15.0 \mathrm{a}$ & $69.5 \mathrm{c}$ \\
\hline
\end{tabular}

Differences among treatments followed by different letters are significant at 0.05 level (least significant difference).

$\mathrm{TCA}=$ trunk cross-sectional area using an FP-428 C/N analyzer (LECO Corp., St. Joseph, MI).

\section{Results}

Leaf and fruit nitrogen status. Leaf $\mathrm{N}$ content increased in a curvilinear fashion as $\mathrm{N}$ supply increased with the value being doubled from the lowest $\mathrm{N}$ supply (T1, $8.8 \mathrm{~g} \mathrm{~N}$ per tree) to the highest $\mathrm{N}$ supply (T4, $105.4 \mathrm{~g}$ $\mathrm{N}$ per tree) (Fig. 2A). In contrast, fruit $\mathrm{N}$ content increased proportionally to increasing $\mathrm{N}$ supply (Fig. 2B).

Yield and fruit quality at harvest. Trees receiving the lowest $\mathrm{N}$ supply (T1, $8.8 \mathrm{~g} \mathrm{~N}$ per tree) had significantly lower yield efficiency, smaller fruit, lower SSC, but firmer fruit than those in T2 (26.4 $\mathrm{g} \mathrm{N}$ per tree), T3 (52.7 g N per tree), and T4 (105.4 g N per tree) treatments (Table 1). Trees in the T3 treatment produced the highest fruit yield and the largest fruit (197.6 g/fruit). Fruit SSC was significantly lower in $\mathrm{T} 1$ than in the other $\mathrm{N}$ treatments, whereas no significant difference was detected among T2, T3, and T4 treatments. Fruit firmness tended to decrease with increasing $\mathrm{N}$ supply.

Fruit color. Fruit in $\mathrm{T} 1$ had the darkest external color (lowest L value) in both the exposed and the shaded sides at 3 weeks before estimated optimum harvest (111 DAFB) and at harvest (Table 2). Hunter "L" values, especially in the shaded side, at 111 DAFB was positively related to $\mathrm{N}$ supply levels. The difference in Hunter "L" values among $N$ treatments was less apparent in the exposed side and with fruit development toward maturity. Difference in the degree of skin redness among four levels of $\mathrm{N}$ supply is an important color parameter. This characteristic was determined by calculating the hue value from a combination of Hunter "a" and " $b$ " values. Fruit "a" value decreased, whereas " $b$ " value increased in response to increasing $\mathrm{N}$ supply. Darker green fruits (higher hue values) were positively related to higher $\mathrm{N}$ supply levels in both the exposed and the shaded sides at 111 DAFB. Furthermore, the differences in hue value between the exposed and the shaded sides of fruit skin became greater as $\mathrm{N}$ supply increased. Fruit in $\mathrm{T} 1$ had average hue value of $20.4^{\circ}$ (red) in the exposed side and $32.8^{\circ}$ (red) in the shaded side. For fruit in T4, however, $40.1^{\circ}$ (reddish orange) and $96.5^{\circ}$ (greenish yellow) were detected in the exposed and the shaded sides at 111 DAFB, respectively. At harvest, no significant difference was detected in the hue value in the skin of the exposed side among treatments, but striking differences were observed in the shaded side. The hue value of the shaded side increased with increasing $\mathrm{N}$ supply with the average hue value being $22^{\circ}$ (red), $66.6^{\circ}$ (orange), $77.2^{\circ}$ (orange yellow), and $128.7^{\circ}$ (greenish yellow) in fruit from T1, T2, T3, and T4, respectively.

Concentrations of anthocyanins and chlorophylls in fruit skin. The fruit skin on the exposed side had low concentrations of anthocyanins at 83 DAFB when pigmentation just began, increased steadily until 111 $\mathrm{DAFB}$, and then increased at a faster rate 


\begin{tabular}{|c|c|c|c|c|c|c|c|c|c|c|c|c|c|c|c|c|}
\hline \multirow{2}{*}{$\begin{array}{l}\text { Treatments } \\
\text { (g N/tree) }\end{array}$} & \multicolumn{8}{|c|}{111 DAFB } & \multicolumn{8}{|c|}{$130 \mathrm{DAFB}$} \\
\hline & \multicolumn{2}{|c|}{$\mathrm{L}$} & \multicolumn{2}{|c|}{$\mathrm{a}$} & \multicolumn{2}{|c|}{$\mathrm{b}$} & \multicolumn{2}{|c|}{ Hue $\left(^{\circ}\right)$} & \multicolumn{2}{|r|}{$\mathrm{L}$} & \multicolumn{2}{|c|}{$\mathrm{a}$} & \multicolumn{2}{|c|}{$\mathrm{b}$} & \multicolumn{2}{|c|}{ Hue $\left(^{\circ}\right)$} \\
\hline 8.8 & $38.6 b^{z}$ & $52.1 \mathrm{c}$ & $38.1 \mathrm{a}$ & $28.7 \mathrm{a}$ & $14.2 \mathrm{c}$ & $17.5 \mathrm{c}$ & $20.4 \mathrm{c}$ & $32.8 \mathrm{c}$ & $75.7 \mathrm{a}$ & $89.4 \mathrm{~b}$ & $11.8 \mathrm{a}$ & $4.0 \mathrm{a}$ & $-3.8 \mathrm{a}$ & $-1.1 \mathrm{~b}$ & $341 \mathrm{a}$ & $22.0 \mathrm{~b}$ \\
\hline 52.7 & $46.3 \mathrm{a}$ & $66.8 \mathrm{ab}$ & $29.4 \mathrm{~b}$ & $1.8 \mathrm{c}$ & $18.7 \mathrm{ab}$ & $29.3 \mathrm{ab}$ & $35.6 \mathrm{~b}$ & $86.0 \mathrm{a}$ & $77.1 \mathrm{a}$ & $96.5 \mathrm{ab}$ & $9.95 \mathrm{a}$ & $0.8 \mathrm{ab}$ & $-0.5 \mathrm{a}$ & $8.3 \mathrm{a}$ & $352 \mathrm{a}$ & $77.2 \mathrm{ab}$ \\
\hline 105.4 & $49.3 \mathrm{a}$ & $69.9 \mathrm{a}$ & $24.4 \mathrm{c}$ & $-3.7 \mathrm{c}$ & $20.3 \mathrm{a}$ & $31.1 \mathrm{a}$ & $40.1 \mathrm{a}$ & $96.5 \mathrm{a}$ & $80.6 \mathrm{a}$ & $101.5 \mathrm{a}$ & $7.0 \mathrm{~b}$ & $-6.7 b$ & $0.7 \mathrm{a}$ & $7.3 \mathrm{a}$ & $362 \mathrm{a}$ & $128.7 \mathrm{a}$ \\
\hline
\end{tabular}

${ }^{\mathrm{z} D i f f e r e n c e s ~ a m o n g ~ t r e a t m e n t s ~ f o l l o w e d ~ b y ~ d i f f e r e n t ~ l e t t e r s ~ a r e ~ s i g n i f i c a n t ~ a t ~} 0.05$ level (least significant difference).

$\mathrm{DAFB}=$ days after full bloom; $\mathrm{L}=$ lightness; $\mathrm{a}=$ redness and greenish; $\mathrm{b}=$ yellowish and bluish; $\mathrm{E}=$ the exposed side $(\mathrm{blush}$ side); $\mathrm{B}=\mathrm{back}$ side (the shaded side).
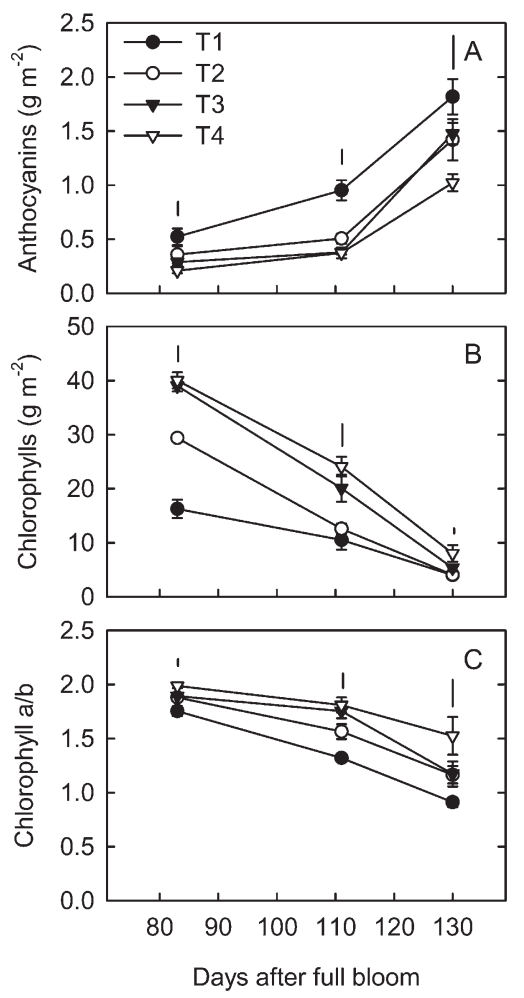

Fig. 3. Effects of nitrogen (N) supply on anthocyanin concentration (A), chlorophyll content (B), and the chlorophyll a/b ratio (C) in 'Gala' skin during fruit development and maturation. The total amount of $\mathrm{N}$ provided in T1, T2, T3, and T4 during the growing season is 8.8, 26.4, 52.7 , and $105.4 \mathrm{~g}$ per tree, respectively. Each point is mean \pm SE of five replicates. The vertical bar above the symbols at each sampling point is the least significant difference at the 0.05 level.

toward maturity (Fig. 3A). At harvest (130 DAFB), skin anthocyanin concentrations in $\mathrm{T} 2$ and $\mathrm{T} 3$ were comparable but were higher than those in T4. In the skin of the fruit from $\mathrm{T} 1$, however, a much higher rate of anthocyanin accumulation occurred from 83 to 111 DAFB, which resulted in a much higher concentration of anthocyanins than those in the other three $\mathrm{N}$ treatments.

Chlorophyll concentrations in fruit skin decreased in all four $\mathrm{N}$ treatments from 83 to 130 DAFB (Fig. 3B). Fruit from trees in T1 had significantly lower chlorophylls than those from the other three $\mathrm{N}$ treatments at 83 DAFB. The decrease in chlorophyll concentrations from 83 to 130 DAFB was significantly delayed by increasing $\mathrm{N}$ supply, although the difference in chlorophyll concentrations tended to dimin-

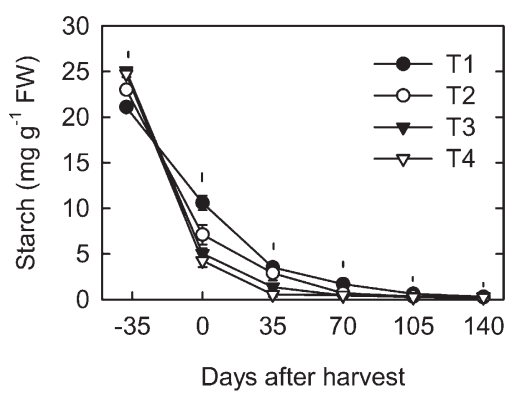

Fig. 4. Effects of nitrogen (N) supply on flesh starch concentration before harvest and during storage. The total amount of $\mathrm{N}$ provided in $\mathrm{T} 1$, $\mathrm{T} 2$, T3, and T4 during the growing season is $8.8,26.4,52.7$, and $105.4 \mathrm{~g}$ per tree, respectively. Each point is mean \pm SE of five replicates. The vertical bar above the symbols at each sampling point is the least significant difference at the 0.05 level.

ish as fruit developed toward maturity. The chlorophyll $\mathrm{a} / \mathrm{b}$ ratio declined from 83 to 130 DAFB with the value being higher at higher $\mathrm{N}$ supply at each sampling point (Fig. 3C).

Fruit starch concentration before and after harvest. Starch concentration in the flesh was higher at higher $\mathrm{N}$ supply at $38 \mathrm{~d}$ before harvest (Fig. 4). Starch concentration underwent a sharp decrease from $38 \mathrm{~d}$ before harvest to harvest, and the slope of the decrease was steeper at higher $\mathrm{N}$ supply, leading to decreased starch concentration with increasing $\mathrm{N}$ supply at harvest. During cold storage, starch degradation continued in all four $\mathrm{N}$ treatments, but starch degradation was completed earlier at higher N supply.

Soluble solids concentration and firmness at harvest and during storage. Soluble solids concentration and firmness displayed noticeable differences in the fruit with different levels of $\mathrm{N}$ supply at harvest and during storage (Fig. 5). At harvest, fruit SSC was significantly higher in T2, T3, and T4 treatments than in T1 treatment. Fruit SSC in T1 increased during cold storage, reached a maximum at $105 \mathrm{~d}$ after harvest (DAH), and then decreased slightly (Fig. 5A). For fruits in the other three $\mathrm{N}$ treatments, however, SSC continued to decrease from harvest to $140 \mathrm{~d}$ after harvest. No significant difference was detected in SSC between any $\mathrm{N}$ treatments after $105 \mathrm{DAH}$.

At harvest, fruit firmness was lower at higher $\mathrm{N}$ supply (Fig. 5B). Fruit firmness decreased linearly from harvest to $140 \mathrm{DAH}$ in all four N supply levels. Fruit firmness was negatively related to the level of $\mathrm{N}$ supply with the highest fruit firmness measured in the lowest $\mathrm{N}$ treatment.

\section{Discussion}

Larger fruit size and higher yield efficiency with increasing $\mathrm{N}$ supply found in this study (Table 1) was expected because our previous work clearly showed that increasing $\mathrm{N}$ supply improves leaf $\mathrm{N}$ status, leaf and whole tree photosynthetic capacity, and leaf area to fruit ratio, leading to more cells per fruit, larger fruit, and higher yield (Xia et al., 2009). Compared with our previous study (Xia et al., 2009), a wider range of $\mathrm{N}$ supply was used and a wider leaf $\mathrm{N}$ status was achieved in this experiment (Fig. 2A), which may explain why fruit size and yield efficiency did not show further responses when $\mathrm{N}$ supply was increased beyond a certain level.

Apple fruit coloration depends on the synthesis of anthocyanins, which is genetically determined but is also influenced by various environmental factors (Walter, 1967). In this study, the skin of fruit in the lowest $\mathrm{N}$ treatment displayed earlier anthocyanin accumulation and higher anthocyanin concentrations than those under higher $\mathrm{N}$ supply (Fig. 3A). Hunter values also showed the same trend. Lowest hue value (reddest) was found in fruit under the lowest $\mathrm{N}$ supply, and darker green fruit (higher hue values) were positively related to higher $\mathrm{N}$ supply levels in both the exposed side and the shaded side at 111 DAFB (Table 2). At harvest, the hue values in the skin of the exposed side in all treatments were statistically similar. In the shaded side, however, the hue value increased with increasing $\mathrm{N}$ supply. These results clearly indicate that low $\mathrm{N}$ supply enhances but high $\mathrm{N}$ supply attenuates anthocyanin synthesis and accumulation in apple skin. This is consistent with what was found in many previous experiments, i.e., fruit skin color decreases with increasing N application (Beattie, 1954; Fallahi et al., 2001, 2006; Magness et al., 1940; Reay et al., 1998; Saito, 1995; Week et al., 1952). In addition to a direct effect, high $\mathrm{N}$ supply could also indirectly affect anthocyanin synthesis and accumulation by stimulating shoot growth, which reduces light exposure of the fruit through shading. However, because only fully exposed fruit on the south side of the tree canopy were used in the current study, this indirect effect would be small for the fruit measured, if any.

Schulz (1986) stressed that intense anthocyanin formation is possible only with the onset or completion of chlorophyll degradation. High 

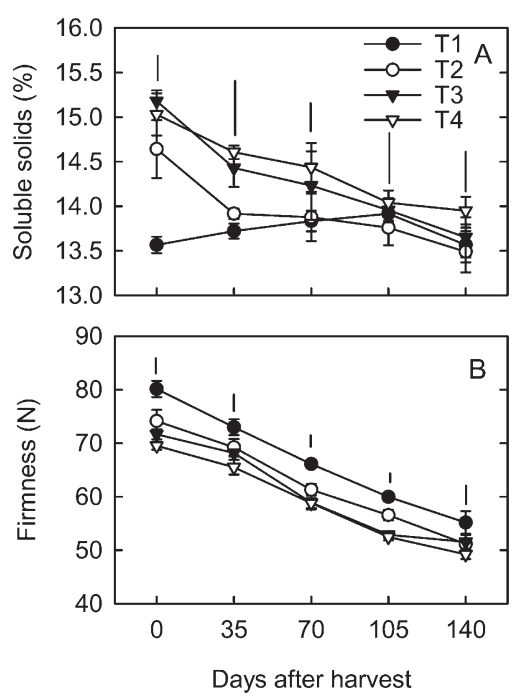

Fig. 5. Effects of nitrogen (N) supply on fruit soluble solids concentration (A) and firmness (B) at harvest and during storage. The total amount of $\mathrm{N}$ provided in $\mathrm{T} 1, \mathrm{~T} 2, \mathrm{~T} 3$, and $\mathrm{T} 4$ during the growing season is 8.8, 26.4, 52.7, and $105.4 \mathrm{~g}$ per tree, respectively. Each point is mean \pm SE of five replicates. The vertical bar above the symbols at each sampling point is the least significant difference at the 0.05 level.

$\mathrm{N}$ nutrition increases chlorophyll concentration but inhibits anthocyanin formation (Saure, 1990). Reger (1944) found an inverse relationship between the presence of chlorophylls and anthocyanins in the epidermal and hypodermal cells of apple. Several observations on green parts of other species confirm that chlorophylls may absorb much of the red light, thus reducing its efficiency in regulating the phytochrome system and, as a result, much higher irradiation is required in green tissues than in etiolated tissues to achieve the same phytochrome control (Jose and Schäfer, 1978; KazarinovaFukshansky et al., 1985). In this study, the skin chlorophyll content and chlorophyll $\mathrm{a} / \mathrm{b}$ deceased with anthocyanin accumulation (Fig. 3B-C). Significantly higher chlorophyll content and chlorophyll $\mathrm{a} / \mathrm{b}$ ratio were found in the skin under higher $\mathrm{N}$ supply. This suggests that the poor fruit color under high $\mathrm{N}$ supply might partly result from high concentrations of chlorophylls present in the fruit skin, which not only mask the display of anthocyanins as surface color, but also delay the synthesis of anthocyanins.

Although skin pigmentation was delayed by high N supply, flesh starch degradation was accelerated by high $\mathrm{N}$ supply (Fig. 4). This is consistent with lower starch indices observed by Neilsen et al. (2006) on 'Gala' and by Fallahi et al. (2001) on 'Fuji' apples under low $\mathrm{N}$ supply. The accelerated starch breakdown under high $\mathrm{N}$ supply might be related to the higher rate of ethylene evolution measured in fruit grown under high $\mathrm{N}$ supply (Fallahi et al., 2001). These differential effects of N supply on skin pigmentation and starch degradation have important implications for maturity management, especially if non-destructive techniques such as hyperspectral near infrared reflectance imaging is used to assess the maturity stage of fruit, which is solely based on two non-destructive spectral indices, i.e., the chlorophyll decrease and the anthocyanin increase (Geyer et al., 2007). If skin coloration is solely used for determining fruit maturity stage, it may overestimate the maturity stage of fruit grown under low $\mathrm{N}$ supply, whereas underestimating the maturity stage of fruit grown under high $\mathrm{N}$ supply. In commercial production, if growers have to wait for better color development on high $\mathrm{N}$ fruit, the fruit may be too advanced in maturity to be stored long-term. Therefore, it is essential to combine assessment of skin color with starch degradation patterns to determine fruit maturity stage before making decisions on optimal harvest time.

The lower SSC measured at harvest in the low $\mathrm{N}$ fruit in this experiment and in our previous study (Xia et al., 2009) is partially caused by delayed starch degradation because SSC actually increased during cold storage in the low $\mathrm{N}$ fruit as a result of continued starch degradation (Figs. 4 and 5A). The decrease in fruit SSC in the other three $\mathrm{N}$ treatments during cold storage indicates that the amount of glucose released from starch degradation did not make up for the loss of sugars to respiration. Apples grown under high $\mathrm{N}$ supply have higher respiration at harvest and during storage (Boynton et al., 1950; Fallahi et al., 1985, 2001; Smock and Boynton, 1944).

Fruit firmness was found to be negatively related to the level of $\mathrm{N}$ supply both at harvest (Table 1) and during cold storage (Fig. 5B). This is consistent with previous findings that greater firmness was associated with lower $\mathrm{N}$ levels in apple fruit (Boynton et al., 1950; Johnston et al., 2002; Reganold et al., 2001; Smock and Boynton, 1944). Because fruit firmness is one of the most important criteria for consumers of apples, the greater firmness in the low $\mathrm{N}$ fruit would be advantageous in the marketplace if the smaller fruit size and lower soluble solids under low $\mathrm{N}$ supply are not weighed more heavily by consumers. Apples under low $\mathrm{N}$ supply also had higher firmness after storage, indicating their better long-term storability.

In conclusion, increasing $\mathrm{N}$ supply delays skin red color development but accelerates flesh starch degradation in 'Gala' apples. These differential effects of $\mathrm{N}$ supply should be taken into account when assessing fruit maturity for optimizing harvest time.

\section{Literature Cited}

Arnon, D.I. 1949. Copper enzymes in isolated chloroplasts. Polyphenoxidase in Beta vulgaris. Plant Physiol. 24:1-5.

Beattie, J.M. 1954. The effect of differential nitrogen fertilization on some of the physical and chemical factors affecting the quality of Baldwin apples. Proc. Amer. Soc. Hort. Sci. 63:1-9.

Boynton, D., A.B. Burrell, R.M. Smock, O.C. Compton, J.C. Cain, and J.M. Beattie. 1950. Responses of McIntosh apple orchards to varying nitrogen fertilization and weather. Cornell Univ. Agr. Sta. Mem. 290.

Chen, L.S., Q. Lin, and A. Nose. 2002. A comparative study on diurnal changes in metabolite levels in the leaves of three crassulacean acid metabolism (CAM) species, Ananas comosus, Kalanchoe daigremontiana and $K$. pinnata. J. Expt. Bot. 53:341-350.

Cheng, L. and R. Raba. 2009. Accumulation of macro- and micronutrients and nitrogen demandsupply relationship of 'Gala'/'Malling 26' apple trees grown in sand culture. J. Amer. Soc. Hort. Sci. 134:3-13.

Fallahi, E., W.M. Colt, C.R. Baird, B. Fallahi, and I.J. Chun. 2001. Influence of nitrogen and bagging on fruit quality and mineral concentrations of 'BC-2 Fuji' apple. HortTechnology 11:462-466.

Fallahi, E., B. Fallahi, and M.M. Seyedbagheri. 2006. Influence of humic substances and nitrogen on yield, fruit quality, and leaf mineral elements of 'Early Spur Rome' apple. J. Plant Nutr. 29:1819-1833.

Fallahi, E., D.G. Richardson, and M.N. Westwood. 1985. Influence of rootstocks and fertilizers on ethylene in apple fruit during maturation and storage. J. Amer. Soc. Hort. Sci. 110:149-153.

Fuleki, T. and F.J. Francis. 1968. Quantitative methods for anthocyanins. 2. Determination of total anthocyanin and degradation index for cranberry juice. J. Food Sci. 33:78-83.

Geyer, M., B. Herold, M. Zude, and I. Truppel. 2007. Nondestructive evaluation of apple fruit maturity on the tree. Veg. Crops Res. Bul. 66:161-169.

Hoagland D.R. and D.I. Arnon. 1950. The waterculture method for growing plants without soil. California Agr. Expt. Sta. Cir. 347.

Hoffman, M.B. 1940. The pre-harvest drop of mature McIntosh apples as influenced by application of nitrogen carrying fertilizers. Proc. Amer. Soc. Hort. Sci. 37:438-442.

Johnston, J.W., E.W. Hewett, and M.L.A.T.M. Hertog. 2002. Post harvest softening of apple (Malus domestica) fruit: A review. N. Z. J. Crop Hort. Sci. 30:145-160.

Jose, A.M. and E. Schäfer. 1978. Distorted phytochrome action spectra in green plants. Planta 138:25-28.

Kazarinova-Fukshansky, N., M. Seyfried, and E. Schäfer. 1985. Distortion of action spectra in photomorphogenesis by light gradients within the plant tissue. Photochem. Photobiol. 41:689-702.

Magness, J.R., L.P. Batjer, and L.O. Regeimbal 1940. Correlation of fruit color in apples to nitrogen content of leaves. Proc. Amer. Soc. Hort. Sci. 37:39-42.

Meheriuk, M., G.H. Neilsen, and E.J. Hogue. 1992 The influence of nitrogen fertilization, season of application, and orchard floor management on fruit quality and leaf mineral content of 'Golden Delicious' apple trees. Fruit Var. J. 46:71-75.

Neilsen, D., G.H. Neilsen, L. Herbert, P. Millard, and S. Guak. 2006. Allocation of dry matter and $\mathrm{N}$ to fruit and shoots in dwarf apple in response to sink size and $\mathrm{N}$ availability. Acta Hort. 721:33-40.

Neilsen, G.H., M. Meheriuk, and E.J. Hogue. 1984. The effect of orchard floor and nitrogen fertilizer on nutrient uptake and fruit quality of 'Golden Delicious' apple trees. HortScience 19:547-550.

Reay, P.F., R.H. Fletcher, and V.J. Thomas. 1998. Chlorophylls, carotenoids and anthocyanin concentrations in the skin of 'Gala' apples during maturation and the influence of foliar applications of nitrogen and magnesium. J. Sci. Food Agr. 76:63-71.

Reganold, J.P., J.D. Glover, P.K. Andrews, and H.R. Hinman. 2001. Sustainability of three apple production systems. Nature 410:926-930

Reger, M.W. 1944. Thiocyanate induced chlorosis predisposes development of anthocyanin by exposing apple skin tissue to more blue-violet light. Proc. Amer. Soc. Hort. Sci. 45:111-112. 
Saito, H. 1995. The influence of heavy application of nitrogen on the tree growth, yield and fruit quality in apples. Bul. Faculty Agr.-Hirosaki Univ. 58:198-314.

Sanchez, E.E., H. Khemira, D. Sugar, and T.L. Righetti. 1995. Nitrogen management in orchards, p. 327-380. In: Bacon, P.E. (ed.). Nitrogen fertilization in the environment. Marcel Dekker, New York, NY.

Saure, M.C. 1990. External control of anthocyanin formation in apple. Sci. Hort. 42:181-218.
Schulz, H. 1986. Aroma- und Farbstoffe, p. 235 341. In: Friedrich, G., D. Neumann, and M. Vogl (eds.). Physiologie der Obstgehölze. 2nd Ed. Akademie, Berlin, Germany.

Smock, R.M. and D. Boynton. 1944. The effects of differential nitrogen treatments in the orchard on the keeping quality of McIntosh apples. Proc. Amer. Soc. Hort. Sci. 45:77-86.

Voss, D.H. 1992. Relating colorimeter measurement of plant color to the Royal Horticultural Society colour chart. HortScience 27:1256-1260.
Walter, T.E. 1967. Factors affecting fruit color in apples: A review of world literature. Rept. East Malling Res. Stat 1966:70-82.

Week, K.D., F.W. Southwick, and M. Drake. 1952. Relationship of leaf nitrogen, potassium content and color development of apple fruit. Proc. Amer. Soc. Hort. Sci. 60:11-15.

Xia, G., L. Cheng, A.N. Lakso, and M.C. Goffinet. 2009. Effects of nitrogen supply on source-sink balance and fruit size of 'Gala' apple trees. J. Amer. Soc. Hort. Sci. 134:126-133. 